\title{
Optimization of Inulinase Production by Stenotrophomonas Maltophila D457 Isolated from Rhizosphere Soil of Musa Acuminata using Garlic Extract
}

\author{
Sharine Navraj, Mobashshera Tariq, Aruna K* \\ Department of Microbiology, Wilson College, Maharashtra, India \\ *Associate Professor, Head of Microbiology department, Wilson College, Mumbai, India \\ arunasam2000@yahoo.co.in
}

\begin{abstract}
Inulin is a non-digestible carbohydrate fructan polymer consisting mainly of $\beta$-2, $1-D$ fructofuranose links. It has several industrial applications like production of chemical compounds, bioethanol, oil and single-cell protein. As a source of inulin, garlic satisfies all the economic demands of industrial technologies because of its low cost and easy availability. In the present study, inulinase producer was isolated from the rhizosphere soil of Musa acuminate using M9-inulin agar plates, and inulinase activity was detected using 1\% Lugol's iodine as an indicator. The best inulinase activity was observed for Stenotrophomonas maltophilia D457, which was identified by morphological, cultural, biochemical characteristics and 16S rRNA gene sequencing analysis. Inulin was extracted from raw garlic with the help of soxhlet apparatus at $70^{\circ} \mathrm{C} / 6 \mathrm{~h}$ using ethanol as solvent. The garlic extract was found to contain $64.8 \mathrm{mg} / \mathrm{ml}$ of inulin as detected by DNSA method. Optimization of various parameters was carried out for inulinase production. Maximum inulinase production of $160 \mathrm{U} / \mathrm{ml}$ was obtained when $2 \%$ inoculum (O.D. 1.0 at $545 \mathrm{~nm}$ ) was grown in M9 medium containing $1 \%$ garlic extract, $1 \%$ ammonium sulphate, $0.2 \% \mathrm{Na}_{2} \mathrm{HPO}_{4}, 0.5 \%$ $\mathrm{K}_{2} \mathrm{HPO}_{4}, 0.2 \% \mathrm{NH}_{4} \mathrm{Cl}, 0.4 \% \mathrm{NaCl}$ and $0.7 \%$ urea, $\mathrm{pH} \mathrm{5}$, at $37^{\circ} \mathrm{C}$ for $24 \mathrm{~h}$ at static conditions. Highest enzyme activity of $170 \mathrm{U} / \mathrm{ml}$ was obtained at $55^{\circ} \mathrm{C}, \mathrm{pH}$ 5. The effect of various metal ions and thermal stabilizers was observed on inulinase activity. It was found that the presence of $\mathrm{Mn}^{2+}$ ions increased the enzyme activity by $108.23 \%$. Also glycerol exhibited a stabilizing effect on the enzyme.
\end{abstract}

Keywords: Inulin, Rhizosphere soil, Inulinase, Garlic, Lugol's iodine, Musa acuminate, Stenotrophomonas maltophilia D457

\section{INTRODUCTION}

Inulin is a linear chain non-structural polysaccharide consisting of $\beta-2,1-\mathrm{D}$-fructofuranose molecules. Most of the inulin containing plants are dicotyledonous, belonging to the Asteraceae and Campanulaceae families, but a small amount is also found in some monocotyledonous plants from the Poaceae, Liliaceae and Amaryllidaceae families [1]. In nature, it is the second most abundant storage carbohydrate after starch. Although the inulinases can be obtained from vegetable and plant sources, microorganisms are the best sources for commercial production of inulinases mainly due to their easy cultivation and high yields of product [2].

Inulin is a very good substrate for the production of inulinases as well as high fructose syrup and fructo-oligosaccharides. Fructose is a sweetener, sweeter than sucrose (upto 1.5 times), with lower cost and has functional properties that enhance flavor, color and product stability [3]. Both fructose and fructo-oligosaccharides can be produced by inulinase via the enzymatic hydrolysis of inulin [2]. Furthermore, fructose metabolism bypasses the known metabolic pathway of glucose and therefore does not require insulin $[4,5]$. Fructose can be obtained by acid hydrolysis of inulin, however, it is easily degraded at a low $\mathrm{pH}$, and the process leads to the formation of difructose anhydrides and undesirable coloured end products [6]. The complete hydrolysis of inulin using inulinase can yield $95 \%$ pure fructose [7].

Inulinases can be divided into exo-inulinases and endo-inulinases. The exo-inulinase removes the terminal fructose residues from the non-reducing end of inulin, whereas the endo-inulinase acts on the internal linkages of the inulin molecule but lacks invertase activity $[8,9]$. Inulinases have different catalytic properties (molecular weight, optimum $\mathrm{pH}$, optimum temperature, stability) depending especially upon their origin [2]. 
Inulin is naturally present in many different foods. Some every day foods, such as asparagus, leek, onions, banana, wheat and garlic are sources of inulin. Since ancient times, garlic has been consumed as a seasoning or spice. Garlic walks the fine line between food and medicine. Among the different substrates studied for inulinase production, raw garlic has shown maximum inulinase activity (524 IU/L) by Streptomyces sp. [10, 11].

Inulinases can be used in a wide range of industrial applications, such as for obtaining ultra-high fructose syrup from inulin [12], producing bioethanol [13], inulo-oligosaccharide [14], single-cell oil and single-cell protein [15], as well as for producing various chemical compounds like citric acid, butanediol, alcohols and lactic acid [16, 17].

Inulinases have been produced using different substrates which are utilized as carbon sources. These include pure inulin as well as agro-industrial waste residues. Naturally occurring inulin-rich materials are the preferred substrates for producing inulinase [2].

Higher temperature optimum of inulinases is an extremely important factor for the application of these enzymes for commercial production of fructose or fructo-oligosaccharides from inulin, since high temperatures $\left(60^{\circ} \mathrm{C}\right.$ or higher) ensure proper solubility of inulin and also prevent microbial contamination [1]. Higher thermostability of the industrially important enzymes also brings down the cost of production because lower amount of enzyme is required to produce the desired product [11].

Fungi, yeast and bacteria are all capable of producing inulinases and many of them have been successfully used for enzyme production. Inulinases are both extra- and intracellular, but some microorganisms have the ability to express this enzyme in both ways [1].

Inulinase activity has been obtained using different mold strains, Aspergillus spp. being the favourite species for inulinase production. A $52.5 \mathrm{IU} / \mathrm{mL}$ inulinase activity was obtained after 96 hours of cultivation with a selected Aspergillus niger strain [18]. Rhizoctonia solani, isolated from soil, had the maximum inulinase activity of $1.792 \mathrm{U} / \mathrm{mL}$ on the second day of cultivation using Jerusalem artichoke powder as carbon source [9]. Chrysosporium pannorum, isolated from soil, was found to be a very active inulinase producer; its highest activity was $115 \mathrm{U} / \mathrm{mL}$ [19].

Yeasts have been used in enzyme production for ages, as they are easier to grow and handle in comparison with bacteria. Among the yeasts that can produce inulinases, Kluyveromyces spp., Pichia spp. and Candida spp. have high potential for producing high yields of inulinase activity. Kluyveromyces spp. is by far the most widely used yeast for inulinase production [11].

\section{MATERIALS AND METHODS}

\subsection{Enrichment and Isolation of Inulinase Producers}

One gram of soil was collected from the rhizosphere region of plant Musa acuminate for enrichment of inulinase producers. The above soil sample was mixed with $10 \mathrm{ml}$ distilled water and allowed to settle for 30mins. Then $1 \mathrm{ml}$ of supernatant was inoculated into $30 \mathrm{ml}$ enrichment broth (M9-Inulin medium- $0.2 \% \mathrm{NaCl}, 0.3 \% \mathrm{Na}_{2} \mathrm{HPO}_{4}, 0.18 \% \mathrm{KH}_{2} \mathrm{PO}_{4}, 0.2 \% \mathrm{NH}_{4} \mathrm{Cl}$ and $1 \%$ inulin: sole source of carbon and energy) and incubated at $30^{\circ} \mathrm{C}$ for $48 \mathrm{~h}$ under shaker (200 rpm) and static conditions. Two subsequent enrichments were carried out after $24 \mathrm{~h}$ each, using $1 \mathrm{ml}$ of culture in $30 \mathrm{ml}$ of fresh medium; after which the single colonies were isolated from M9-inulin agar [20].

\subsection{Screening of Inulinase Producers}

The isolates obtained from M9-Inulin agar plates were spot inoculated on MHI agar plates and incubated at $30^{\circ} \mathrm{C}$ for 3 days. It was then flooded with $5 \mathrm{ml}$ of $1 \%$ Lugol's iodine and examined for a zone of clearance around the colony which indicated the presence of the enzyme inulinase [20]. Further, inulinase assay of the promising isolate was carried out to confirm inulinase production.

\subsection{Identification of Inulinase Producers}

Inulinase producers were identified using, morphological, cultural and biochemical tests. Further confirmation of the strain was done by $16 \mathrm{~S}$ rRNA sequence analysis by SciGenom Labs Pvt Ltd. Kerala, India.

\subsection{Extraction and Assay of Inulinase Enzyme}

Inulinase activity of the screened isolates was assayed by a method suggested by Miller [21]. The test organisms were grown in M9-inulin broth overnight at $30^{\circ} \mathrm{C}$, and crude enzyme was obtained by centrifuging the broth at 3,500 rpm for 10min. The supernatant obtained was used as a crude enzyme 
for inulinase assay. This crude enzyme $(0.5 \mathrm{ml})$ was mixed with $2 \mathrm{ml}$ of $0.2 \%$ inulin prepared in distilled water and $2 \mathrm{ml}$ of $50 \mathrm{mM}$ acetate buffer $(\mathrm{pH} 4.6)$ incubated at $55^{\circ} \mathrm{C}$ for $20 \mathrm{~min}$. After incubation the reaction mixture was kept in ice water bath for $10 \mathrm{~min}$. to stop the reaction. One $\mathrm{ml}$ of DNSA reagent was added to $1 \mathrm{ml}$ of the above mixture and kept in boiling water bath for $10 \mathrm{~min}$. It was cooled and $6 \mathrm{ml}$ of distilled water was further added to this mixture. The absorbance of the supernatant was measured at $540 \mathrm{~nm}$ using a spectrophotometer. The reaction mixture containing heat inactivated crude enzyme $\left(100^{\circ} \mathrm{C}\right.$ for $\left.10 \mathrm{~min}\right)$ instead of the active culture supernatant was used as blank. The absorbance of the test supernatant against blank was obtained and plotted on the standard graph of Fructose $(40-4000 \mu \mathrm{g} / \mathrm{ml})$ to obtain the amount of product formed. From the standard graph value, enzyme activity was calculated in $\mathrm{U} / \mathrm{ml}$. One unit of enzyme activity is defined as the amount of enzyme liberating $1 \mu$ mole of fructose per minute under standard conditions.

\subsection{Screening of Various Media for Optimum Enzyme Activity}

Four different media viz. Medium 1 [22], Medium 2 [9], Medium 3 [4] and Medium 4 (M9 with 1\% inulin as a sole carbon source) were tested for maximum inulinase production by selected isolates. The medium showing highest enzyme activity was used for carrying out further analysis.

\subsection{Optimization of Growth Conditions for Maximum Inulinase Production}

Optimization of culture conditions for the highest inulinase production was studied in M9 medium with $1 \%$ Inulin. Two percent inoculum $\left(0.8 \mathrm{OD}_{545 \mathrm{~nm}}\right)$ was used to carry out all further analysis. The growth conditions (incubation period, aeration, temperature and $\mathrm{pH}$ ) were optimized for maximum inulinase production by the selected isolate. Inulinase production was determined at various time intervals such as $12,24,36,48,60$ and $72 \mathrm{~h}$. The effect of aeration on inulinase production was studied by incubating one culture flask on shaker (200rpm) and other under static condition at $\mathrm{RT} / 24 \mathrm{~h}$. Optimum temperature for inulinase production was determined by carrying out the incubation of test isolates at $30^{\circ} \mathrm{C}, 37^{\circ} \mathrm{C}, 45^{\circ} \mathrm{C}, 55^{\circ} \mathrm{C}$ and $70^{\circ} \mathrm{C}$ for $24 \mathrm{~h}$. Optimum $\mathrm{pH}$ for inulinase production was determined by measuring the enzyme activity at different $\mathrm{pH}$ range from 4 to $10(1 \mathrm{~N}$ $\mathrm{NaOH}$ and $1 \mathrm{~N} \mathrm{HCl}$ were used for adjusting $\mathrm{pH}$ of the medium).

\subsection{Optimization of Media Composition for Maximum Inulinase Production}

The optimization of nutrient (carbon and nitrogen sources) and salt $\left(\mathrm{K}_{2} \mathrm{HPO}_{4}, \mathrm{Na}_{2} \mathrm{HPO}_{4}, \mathrm{NaCl}\right.$ and $\mathrm{NH}_{4} \mathrm{Cl}$ ) concentration was carried out at using the medium giving highest enzyme activity and incubated at appropriate temperature and conditions. After incubation, the medium was centrifuged at $3500 \mathrm{rpm}$ for 10min and the supernatant was used as a crude enzyme for studying the effect of nutrient and salt supplements on enzyme activity. Effect of different carbon sources on inulinase production was checked by adding $1 \% \mathrm{w} / \mathrm{v}$ of glucose, fructose and sucrose in M9 medium. The effect of these carbon sources was also determined when it was added along with inulin in M9 medium (inulin+glucose, inulin+fructose and inulin+sucrose). Optimized sugar $(0.5-2 \% \mathrm{w} / \mathrm{vat}$ increments of $0.5 \%$ ) was tested for higher yield of inulinase. Different organic and inorganic nitrogen sources $(0.5 \%)$ such as casein, peptone, yeast extract, urea, sodium nitrate and potassium nitrate were checked for the maximum inulinase production. In addition, optimized nitrogen source was tested $(0.5-1 \%$ with $0.1 \%$ increment) for maximum inulinase yield. The optimal salt concentrations $(0.1-0.5 \% \mathrm{w} / \mathrm{v}$ with interval of $0.1 \%$ ) of $\mathrm{K}_{2} \mathrm{HPO}_{4}, \mathrm{Na}_{2} \mathrm{HPO}_{4}, \mathrm{NaCl}$ and $\mathrm{NH}_{4} \mathrm{Cl}$ were determined for the highest inulinase production.

\subsection{Effect of Different Physicochemical Parameters on Inulinase Activity}

Inulinase enzyme from the new isolate was assayed to determine the optimum conditions of temperature and $\mathrm{pH}$. Two $\mathrm{ml}$ of inoculum $\left(0.8 \mathrm{OD}_{545 \mathrm{~nm}}\right)$ was inoculated in $100 \mathrm{ml}$ of optimized medium and conditions. Cell-free culture supernatant was obtained by centrifugation at 3,500 rpm for $10 \mathrm{~min}$ and used for the assays. Crude inulinase enzyme from the culture supernatant of optimized M9-inulin medium was assayed in the reaction mixture containing $0.5 \mathrm{ml}$ crude enzyme, $2 \mathrm{ml}$ of $0.2 \%$ inulin, $2 \mathrm{ml}$ of acetate buffer ( $\mathrm{pH}$ ) and incubated at $55^{\circ} \mathrm{C}$ for $20 \mathrm{mins}$. The tubes were then kept in ice bath for the enzyme reaction to stop. One $\mathrm{ml}$ of DNSA reagent was added to one ml reaction mixture and was kept in boiling water bath for 10 minutes. It was allowed to cool down and $6 \mathrm{ml}$ distilled water was added into it. Absorbance was measured at 540nm.The optimal temperature was determined from $30-70^{\circ} \mathrm{C}$ with interval of $5^{\circ} \mathrm{C}$. The inulinase was assayed at various $\mathrm{pH}$ ranging from 4 to 10 in the following buffer systems: $0.1 \mathrm{M}$ Acetate buffer (pH range 4-6), 0.1M Phosphate buffer 
(pH range 7-8) and 0.1M Glycine- $\mathrm{NaOH}$ buffer ( $\mathrm{pH}$ range 9-12). Effect of metals on enzyme activity was measured with different metals namely $\left(0.1 \%\right.$ w/v) $\mathrm{HgCl}_{2}, \mathrm{MgCl}_{2}, \mathrm{ZnCl}_{2}, \mathrm{CaCl}_{2}, \mathrm{KCl}, \mathrm{NaCl}$, $\mathrm{CdCl}_{2}$ and $\mathrm{MnCl}_{2}$. The control was kept with enzyme without metals (100\%). Also, the effects of various thermal stabilizers such as $0.1 \%$ (v/v) glycerol, mannitol and propanol were examined on the inulinase activity The crude enzyme was pre-incubated with above mentioned respective metal ions and thermal stabilizers (with control) for 30 minutes at $30^{\circ} \mathrm{C}$. The residual activity (\%) was measured by standard inulinase assay [22, 23, 24].

\subsection{Analysis of Hydrolysis Products of Inulinase by Thin Layer Chromatography (TLC)}

The end products of the enzyme reaction were visualized using thin layer chromatography. The hydrolysis product sample of the enzyme and garlic extract was spotted on pre coated TLC plate. $1 \%$ fructose, $1 \%$ inulin was used as standards. The solvent system used was acetone: water (9:1) and iodine was used as developing reagent [25].

\section{RESUlts AND DisCUSSION}

\subsection{Enrichment, Isolation and Screening of Inulinase Producers}

The soil sample from rhizosphere area of plant Musa acuminata was enriched in M9-inulin broth containing $1 \%$ inulin as a sole source of carbon. Enriched sample was streaked on M9-inulin agar plates and incubated at $30^{\circ} \mathrm{C}$ for $24 \mathrm{~h}$. Total 4 isolates were obtained which were designated as GS-1, GS-2, GS-3 and GS-4. Inulinase producers were screened with the help of lugol's iodine which on addition to the medium, showed zone of hydrolysis around the colony on MHI agar plates confirming extracellular inulinase activity (Figure 1). All four isolates were assayed for inulinase activity which was found to be $156 \mathrm{U} / \mathrm{ml}, 136 \mathrm{U} / \mathrm{ml}, 141.5 \mathrm{U} / \mathrm{ml}$ and $144 \mathrm{U} / \mathrm{ml}$ for GS-1, GS-2, GS-3 and GS-4 respectively (Figure 2). GS-1 was found to give maximum enzyme activity and hence further studies were carried out using this isolate.

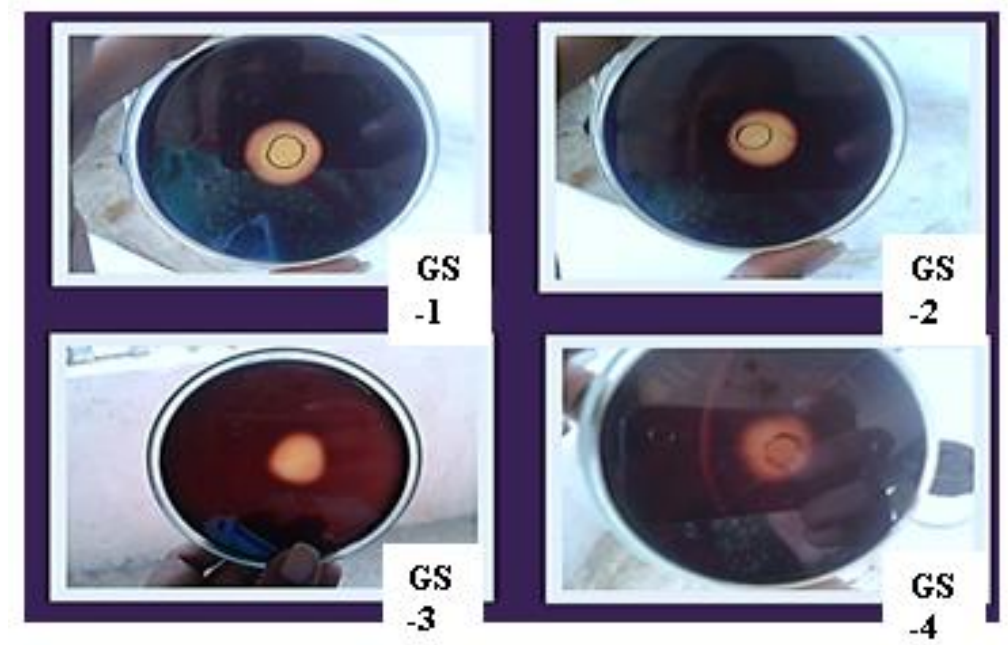

Figure1. Screening of Inulinase Producers on MHI Agar Plates

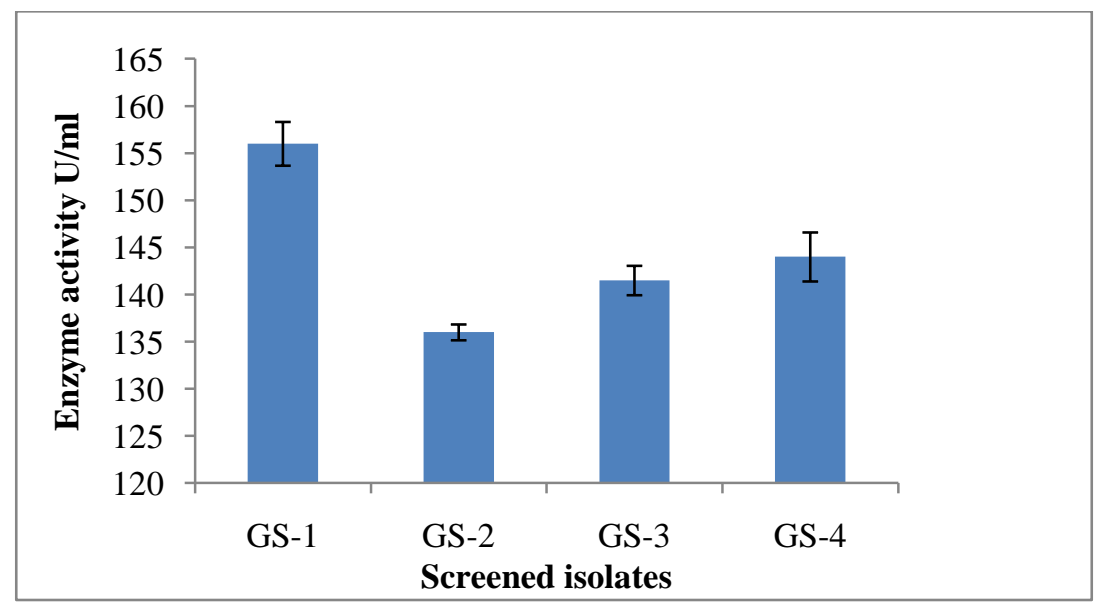

Figure2. Enzyme Activity of Inulinase Producers 


\subsection{Identification of Inulinase Producers}

The selected GS-1 isolate was identified preliminarily by standard morphological, cultural, biochemical methods and confirmed by16S rRNA gene sequencing analysis as Stenotrophomonas maltophila D457. It is a gram negative, aerobic, non-fermentative, rod shaped bacteria. There are very few published data on gram negative inulinase producers which include Marinimicrobium spp., Pseudomonas spp., LS-A18 and Acinetobacter baumanii $[20,24,26]$. Among the gram positive isolates, extensive data is available on Bacillus spp. as a potential inulinase producer. Extracellular inulinase production has been studied by Zherebtsov et al. on Bacillus polymyxa 29, B. polymyxa 722 and B. subtilis 68 [27]. Similarly exoinulinases are known to be produced by Bacillus sp. B51f [28], Bacillus cereus MU-31 [29], Staphylococcus spp. RRL-M-5 [30], Clostridium thermoautotrophicum [31] etc. In addition, many actinomycetes, fungus and yeasts are also known to produce inulinase enzyme [32, 33, 34].

\subsection{Optimization of Growth Conditions for Maximum Inulinase Production}

Among the various media screened for optimum inulinase production, media 4- M9 medium with $1 \%$ inulin showed highest activity, and hence it was used for all further optimization studies (Figure $3)$. Presence of inulin in the M9-Inulin medium induced maximum inulinase production by $S$. maltophila D457 which supports the fact that inulinase is an inulin inducible enzyme. A variety of media have been used previously by various scientists for the production of inulinase by different microbes viz. Beef extract agar for Bacillus sp. [27], Czapex Dox agar for Streptomyces sp. [29], yeast extract peptone dextrose (YPD) medium for yeast [35], Potato Dextrose medium for Aspergillus sp. [36], Mineral medium for Bacillus sp. [30], IB medium [37] and MHI medium for Marinimicrobium [20].

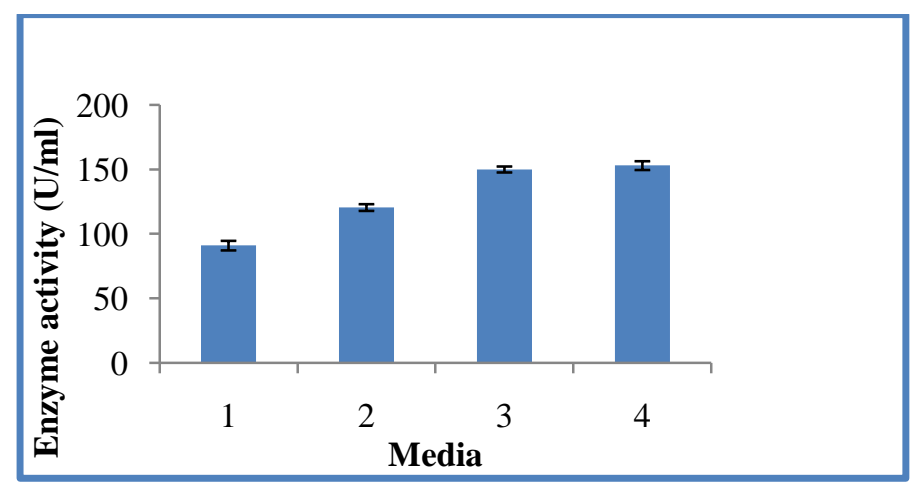

Figure3. Effect of Different Media on Inulinase Production by S. Maltophila D457

The optimum incubation period for inulinase production was found to be $24 \mathrm{~h}$. The enzyme production was found to be nearly doubled during the initial period of $12-24 \mathrm{~h}$. However, beyond $24 \mathrm{~h}$, it showed a decrease in enzyme production. Similar results were also reported for A.baumanii [26] and Bacillus sp. B51f [28]. This could be either due to the inactivation of the enzyme because of the presence of some kind of proteolytic activity or the growth of the organism might have reached a stage from which it could no longer balance its steady growth with the availability of nutrient source [26]. By using the optimized fermentation parameters, the enzymatic activity was at lowest values in the lag phase and increased during the exponential phase.

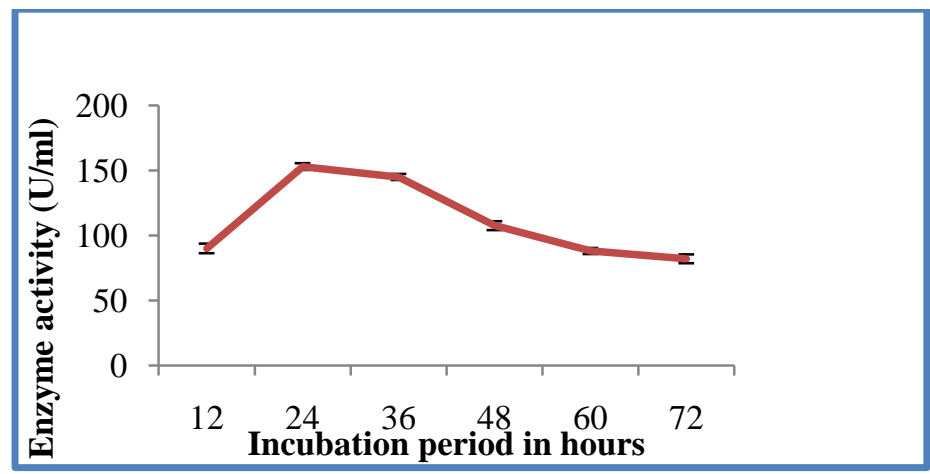

Figure4. Effect of Incubation Period on Inulinase Production by S. Maltophila D457 
Inulinase production by $S$. maltophila D457 was found to be the maximum under static conditions (Figure 5). However, Marinimicrobium sp. LS-A18 showed maximum inulinase production under shaker condition [20]. In this study aeration has been found to have an adverse effect on inulinase production which resulted in low enzyme activity. Aeration showed a decrease in the inulinase production in Bacillus sp. B51f [28] Kluyveromyces marxianus YS-1 [38] and Staphylococcus sp. RRL-1 [39].

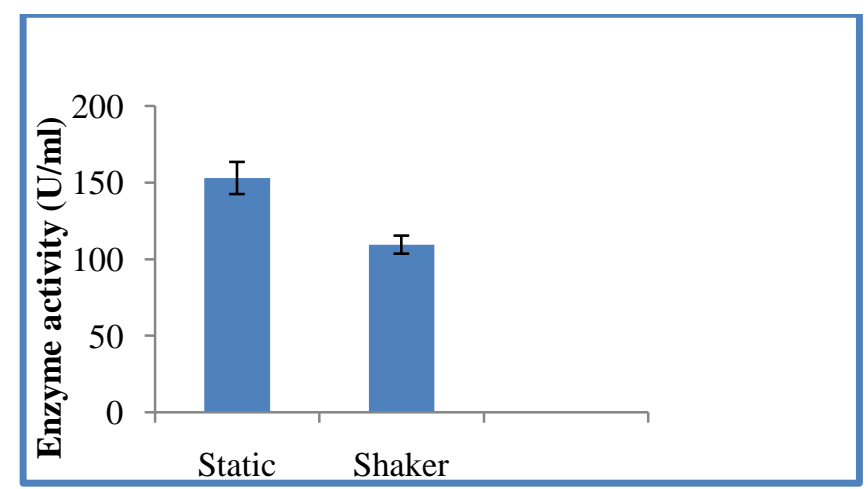

Figure5. Effect of static and shaker conditions on inulinase production by S. maltophila D457

The maximum production of inulinase by $S$. maltophila $\mathrm{D} 457$ was obtained at $37^{\circ} \mathrm{C}$. The production of inulinase was found to decrease with the increase in temperature. These results may be due to the decrease in growth rate at higher temperature. Similar results were obtained from gram negative organisms like Marinimicrobium sp. LS-A18 and Xanthomonas sp that showed maximum inulinase production at $37^{\circ} \mathrm{C}[20,40]$. Another study reported maximum inulinase production at $28^{\circ} \mathrm{C}$ for A.baumanii [26]. Park and Yun, 2001 reported maximum inulinase production at $42^{\circ} \mathrm{C}$ by Pseudomonas spp. [41]. Inulinase production has been observed in a broad temperature range of 20$50^{\circ} \mathrm{C}$ [30]. A study reported that the enzyme production was inhibited at $55^{\circ} \mathrm{C}$ and at $60^{\circ} \mathrm{C}$ the enzyme production was rapidly lost [41]. Low inulinase production at higher temperature could be due to the reduction of oxygen solubility in the medium, or enzyme denaturation [42].

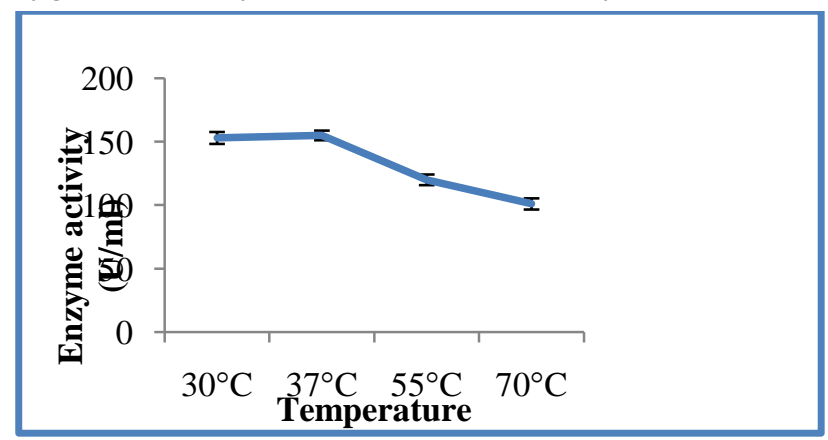

Figure6. Effect of Incubation Temperature on Inulinase Production by S. Maltophila D457

The optimal $\mathrm{pH}$ for maximum inulinase production was observed at $\mathrm{pH} \mathrm{5}$, and it was found to decrease with the increase in alkalinity (Figure 7). Similar findings were observed for Erwinia sp. (pH 6.0), Streptomyces sp. ALKC4 (pH 6.0), and Pseudomonas sp. (pH 6.5) which showed their optimum $\mathrm{pH}$ in the acidic range $[10,43,44]$. In contrast to our finding, maximum production of inulinase was reported to be at neutral $\mathrm{pH}$ for Bacillus sp. B51f [28] and Xanthomonas campestris [45] and, in the alkaline range for Marinimicrobium sp. LS-A18 (pH 9) and A.baumanii (pH 7.5) [20, 26].

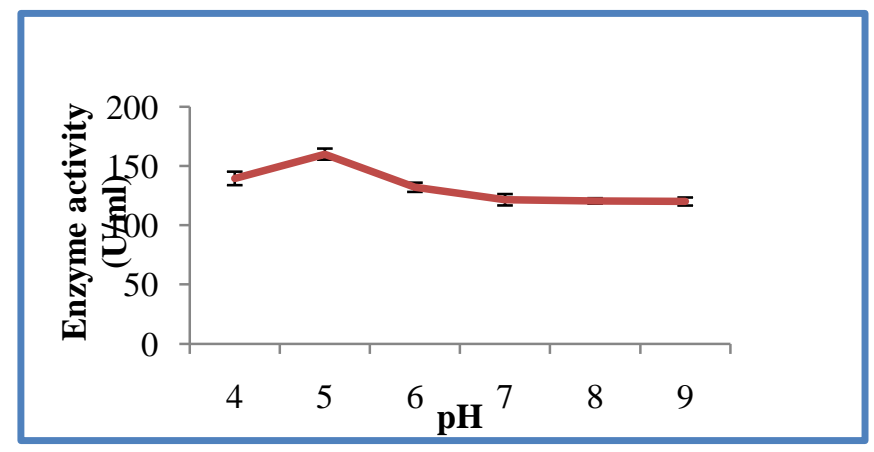

Figure7. Effect of PH on Inulinase Production by S. Maltophila D457 


\subsection{Optimization of Carbon Sources for Maximum Inulinase Production}

To investigate the effect of carbon sources on inulinase production, the garlic extract was replaced with other carbon sources. Figure 8 shows the effect of various carbon sources on inulinase production by S. maltophila D457 and Figure 9 shows the optimization of concentration of garlic extract for maximum inulinase activity. Maximum activity was observed with $1 \%$ garlic extract as compared to other carbon sources by S. maltophila D457. It was observed that inulinase production was severely suppressed by most of the carbon sources, indicating that inulinase production is inducible in S. maltophila D457. Other studies have also reported inducible nature of inulinase enzyme [20, 26, 46, 47, 48]. Conversely, Ayyachamy et al, 2007, reported that the inulinase production by Xanthomonas campestris was constitutively expressed, and was not inducible [45]. In addition to garlic as a carbon source, sugarcane, molasses and sugar beet molasses were found to support inulinase activity, whereas glucose, lactose, galactose, arabinose and soluble starch showed a repressive effect on inulinase enzyme activity [11]. Inulin was reported to be the best carbon source for inulinase production by A.baumanii and Xanthomonas oryzae [26, 49]. It was reported that Bacillus polymyxa 722 and Bacillus polymyxa 29 displayed the maximal activity on a starchcontaining culture medium, while the maximal activity of Bacillus subtilis 68 was observed in the presence of sucrose. All of these results suggested that different regulation mechanisms exist in these strains [27].

Enzyme activity of S. maltophila D457 showed repression when grown with mixed substrates such as garlic extract along with sucrose, glucose or fructose hence further confirming that inulinase is an inducible enzyme in S. maltophila D457 (Figure 8). Earlier study showed appreciable inulinase activity by Acinetobacter spp. with substrates such as rye (313 IU/L), barley (244 IU/L), banana (283 $\mathrm{IU} / \mathrm{L})$, wheat $(320 \mathrm{IU} / \mathrm{L})$, chicory $(328 \mathrm{IU} / \mathrm{L})$ and onion $(300 \mathrm{IU} / \mathrm{L})$. This activity was similar to the activity obtained by using pure inulin (321 IU/L) as a sole carbon source [10].

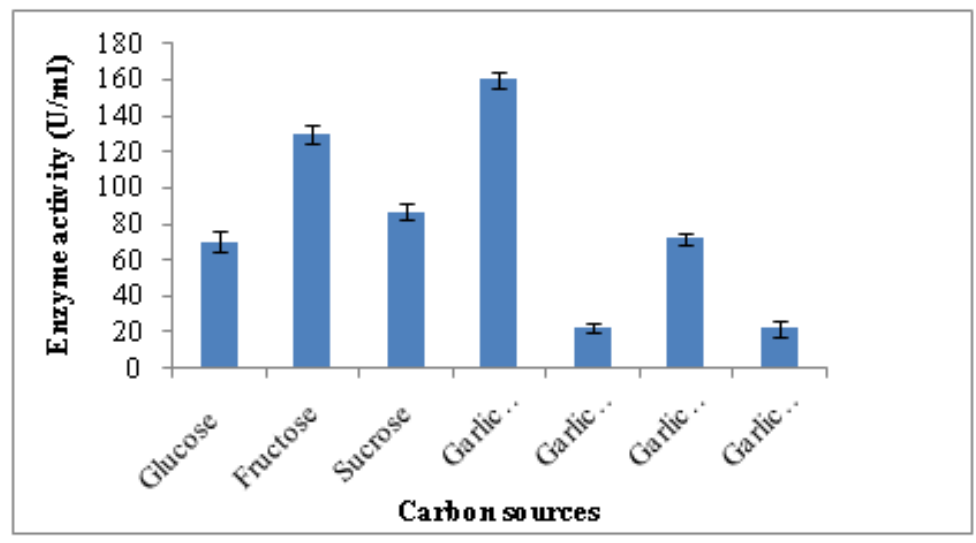

Figure8. Effect of Carbon Sources on Inulinase Production by S. Maltophila D457

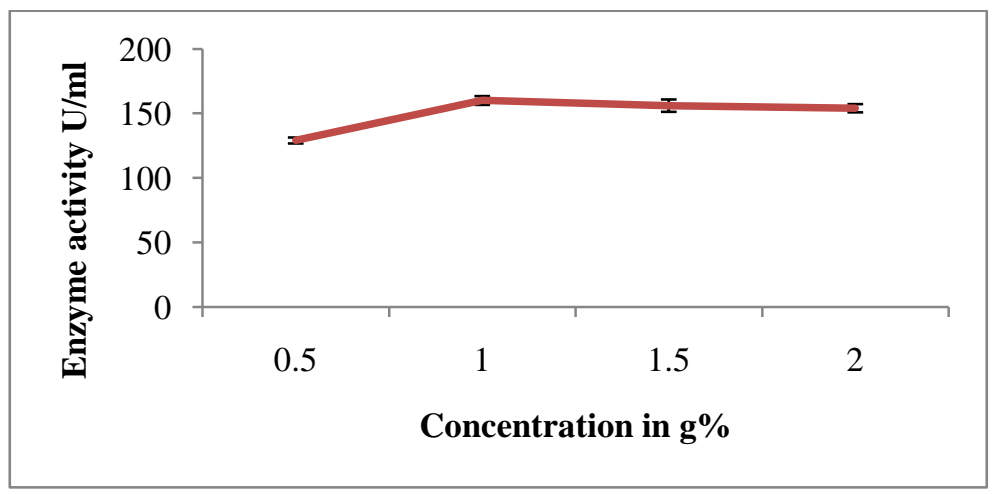

Figure9. Optimization of the Concentration of Garlic Extract on Inulinase Production by S. Maltophila D457

\subsection{Optimization of Nitrogen Sources for Maximum Inulinase Production}

Besides carbon source, the type of nitrogen source in the medium also influences the inulinase yield in production broth. The present finding indicated that the presence of urea in the medium resulted in maximum enzyme activity of $159 \mathrm{U} / \mathrm{ml}$ as compared to other sources like peptone, casein, ammonium 
sulphate, sodium nitrate and potassium nitrate (Figure 10). Figure 11 shows the optimization of urea concentration for maximum enzyme activity was observed to be $0.7 \%$. Urea also significantly improved the inulinase activity of Aspergillus niger NRRL 3 [11]. In contrast to our findings, tryptone was found to be the most effective substrate for inulinase production by A.baumanii [26].

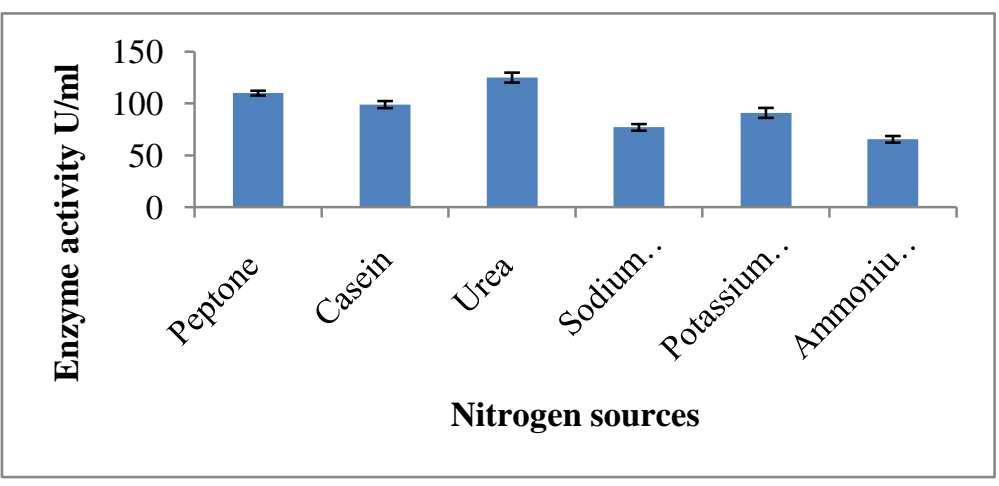

Figure10. Effect of Nitrogen Sources on Inulinase Production by S. Maltophila D457

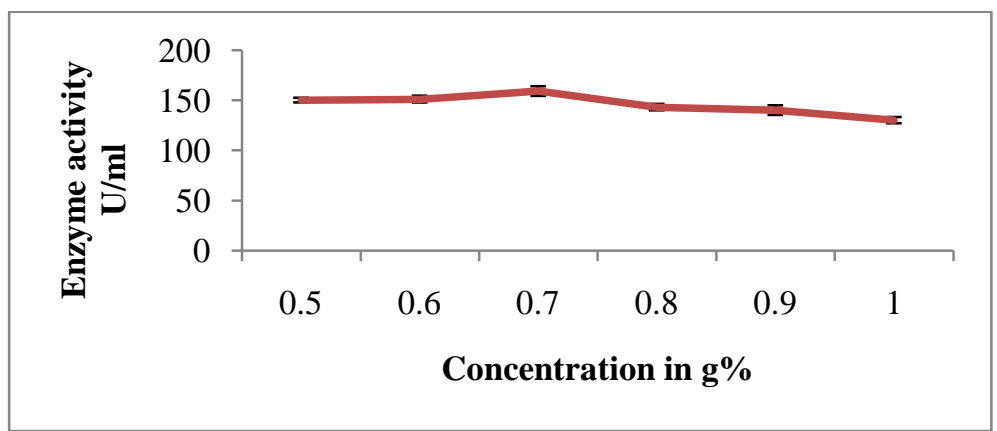

Figure11. Optimization of the Concentration of Urea on Inulinase Production by S. Maltophila D457

\subsection{Optimization of Salt Concentrations for Maximum Inulinase Production}

Maximum inulinase activity was obtained in presence of $0.5 \% \mathrm{~K}_{2} \mathrm{HPO}_{4}$ (Figure 12), $0.2 \% \mathrm{Na}_{2} \mathrm{HPO}_{4}$ (Figure 13), $0.2 \% \mathrm{NH}_{4} \mathrm{Cl}$ (Figure 14) and $0.4 \% \mathrm{NaCl}$ (Figure 15).

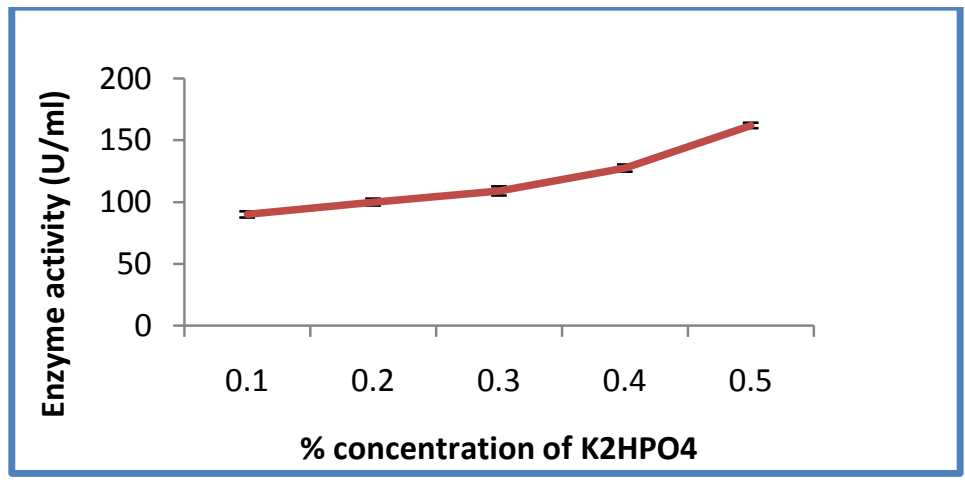

Figure12. Optimization of $\mathrm{K}_{2} \mathrm{HPO}_{4}$ Concentration for Inulinase Production by S. Maltophila D457

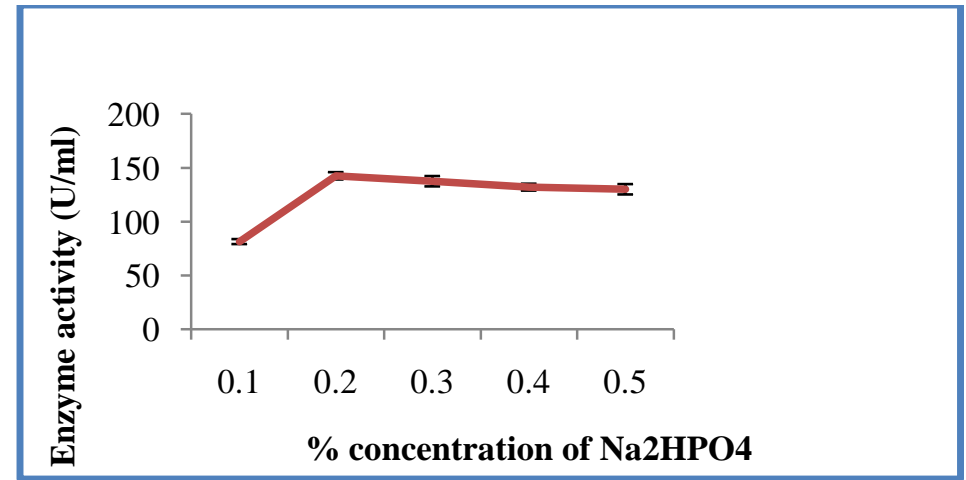

Figure13. Optimization of $\mathrm{Na}_{2} \mathrm{HPO}_{4}$ Concentration for Inulinase Production by S. Maltophila D457 


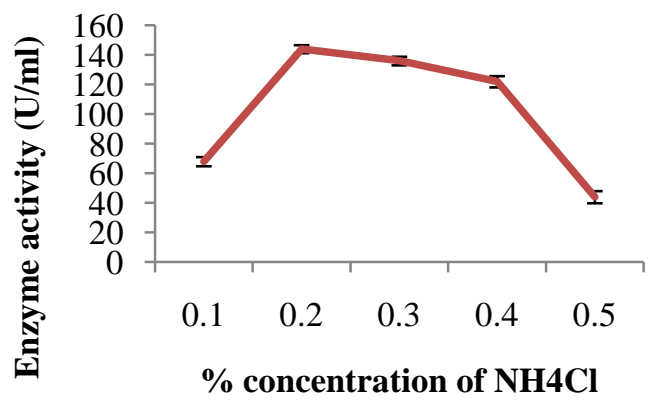

Figure14. Optimization of $\mathrm{NH}_{4} \mathrm{Cl}$ Concentration for Inulinase Production by S. Maltophila D457

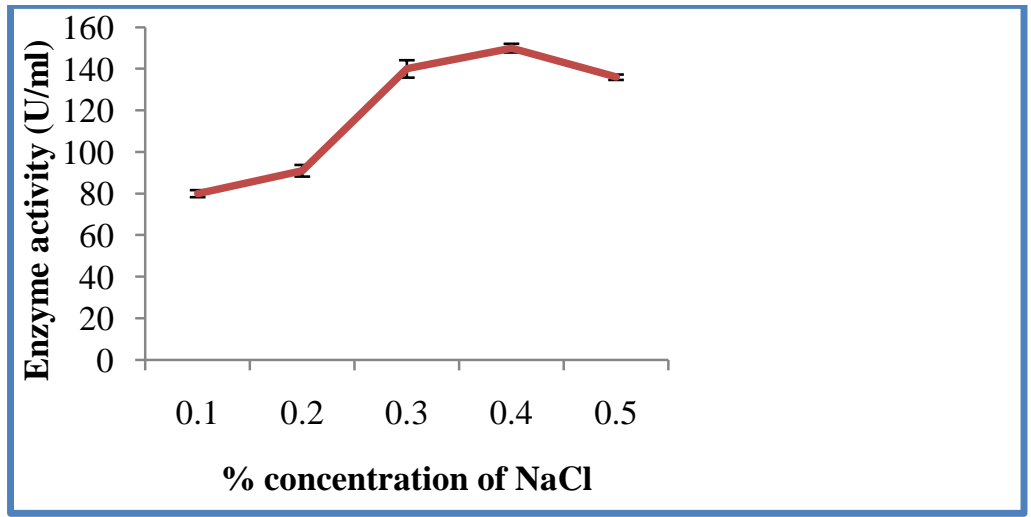

Figure15. Optimization of Nacl Concentration for Inulinase Production by S. Maltophila D457

\subsection{Effect of Different Physicochemical Parameters on Inulinase Activity}

S. maltophila D457when cultivated in M9-Inulin medium containing $1 \%$ garlic extract, $0.7 \%$ urea, $0.5 \% \mathrm{~K}_{2} \mathrm{HPO}_{4}, 0.2 \% \mathrm{Na}_{2} \mathrm{HPO}_{4}, 0.2 \% \mathrm{NH}_{4} \mathrm{Cl}$ and $0.4 \% \mathrm{NaCl}$ at $\mathrm{pH} 5$, temperature $37^{\circ} \mathrm{C}$ for 24 hours at static conditions exhibited maximum inulinase yield. Inulinase enzyme from the culture supernatant of optimized M9-Inulin medium grown with S. maltophila D457 was assayed in the reaction mixture containing $0.5 \mathrm{ml}$ crude enzyme, $2 \mathrm{ml}$ of $0.2 \%$ inulin, $2 \mathrm{ml}$ of acetate buffer $(\mathrm{pH} 5)$ and incubated at $55^{\circ} \mathrm{C}$ for $20 \mathrm{~min}$.

The inulinase enzyme from S. maltophila D457 was found to be more active in an acidic range as compared to alkaline range with an optimum of $\mathrm{pH} 5$ (Figure 16). Similar results were observed for Acetobacter diazotropicus SRT4 and Clostridium acetobutylicum which showed an optimum of $\mathrm{pH}$ $5.5(50,51)$. However, this optimum $\mathrm{pH}$ was lower compared to Marinimicrobium sp. LS-A18 and Bacillus sp. B51f which showed maximum activity at alkaline $\mathrm{pH}(20,28)$.

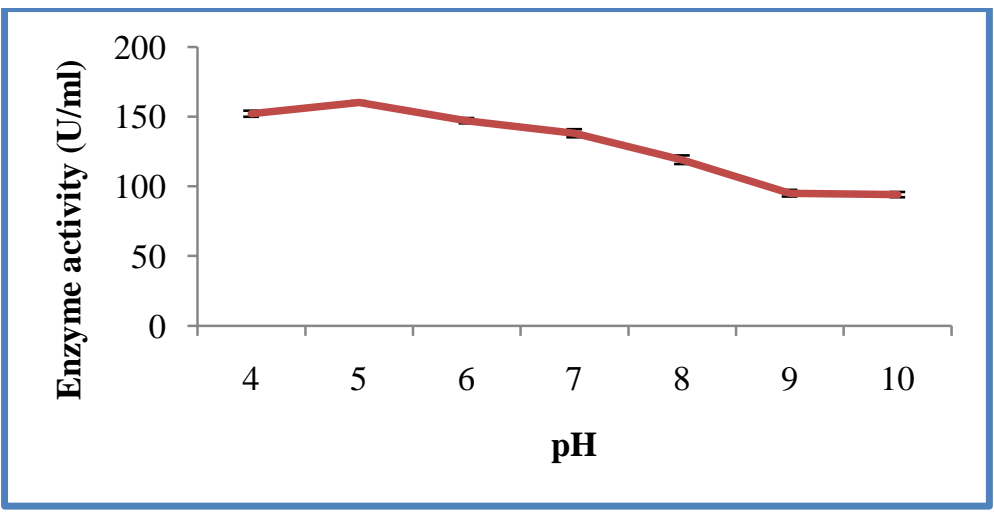

Figure16. Effect of Different $p H$ on Activity of Inulinase from S. Maltophila D457

Bacterial inulinases generally have temperature optima in the range $30-60^{\circ} \mathrm{C}$ [32]. The Inulinase enzyme from S. maltophila $\mathrm{D} 457$ demonstrated optimum activity at $55^{\circ} \mathrm{C}$ but it also retained enzyme activity between $30^{\circ} \mathrm{C}$ to $70^{\circ} \mathrm{C}$ indicating its thermostable nature (Figure 17). Similar results were also 
observed for exoinulinase from the bacterium Geobacillus stearothermophilus KP1289 which was active between $30^{\circ} \mathrm{C}$ and $75^{\circ} \mathrm{C}$ with an optimum at $60^{\circ} \mathrm{C}$ [52] whereas the inulinase from B. subtilis $430 \mathrm{~A}$ was stable at an optimal temperature of $45-50^{\circ} \mathrm{C}$ [42]. In contrast, the exoinulinase activity produced by B. polymyxa MGL21 is optimal at $35^{\circ} \mathrm{C}[53]$.

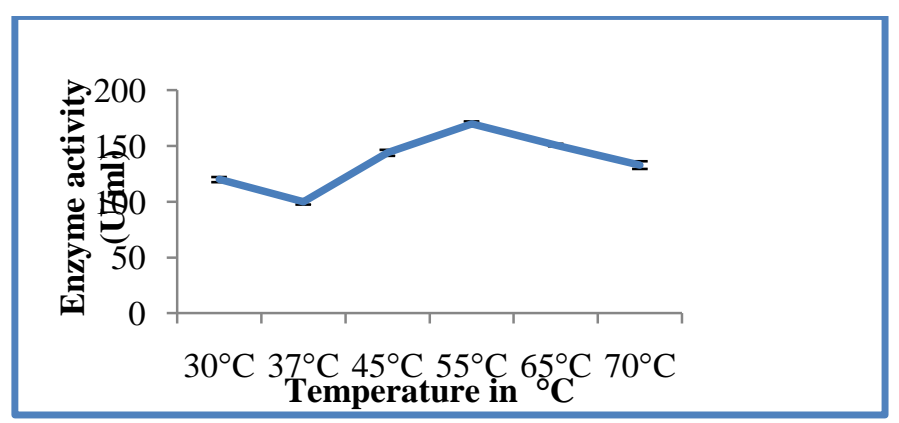

Figure17. Effect of Temperature on Activity of Inulinase from S. Maltophila D457

In an attempt to further characterize the inulinase enzyme from $S$. maltophila D457; various metal ions were tested on inulinase enzyme activity. Residual activity of the inulinase enzyme was positively enhanced by $\mathrm{Mn}^{2+}$ and was inhibited in presence of $\mathrm{Fe}^{3+}$ by $63.52 \%$ (Figure 18). Similar results were reported for pure inulinase enzyme from Streptomyces grisenus; it was stable in the presence of $\mathrm{CaCl}_{2}$ and was inhibited by compounds such as $\mathrm{ZnSO}_{4}, \mathrm{MgSO}_{4}, \mathrm{MnSO}_{4}, \mathrm{FeSO}_{4}, \mathrm{CuSO}_{4}$ and $\mathrm{MnCl}_{2}$ [54] while $\mathrm{Zn}^{2+}$ and $\mathrm{Hg}^{2+}$ were inhibitors for inulinase from P. mucidolens [55]. $\mathrm{Mg}^{2+}$, $\mathrm{Mn}^{2+}$ and $\mathrm{Co}^{2+}$ strongly activated the enzyme activity in Streptomyces CP01 [56]. There have been reports that $\mathrm{Mn}^{2+}$ and $\mathrm{Co}^{2+}$ activated the activity of inulinases from Aspergillus niger Mutant 817 [57] and Kluyveromyces marxianus YS-1 [38]. The negative effect of ions on the inulinase is generally the result from direct inhibition of the catalytic site like many other enzymes. Residual activity of inulinase enzyme was found to be inhibited by $\mathrm{Cu}^{+2}, \mathrm{Fe}^{+3}, \mathrm{Zn}^{+2}$ in Kluyveromyces marxianus [38]. $\mathrm{Mg}^{2+}, \mathrm{Hg}^{2+}$, and $\mathrm{Ag}^{+2}$ acted as inhibitors in decreasing the activity of the purified inulinase of Crytococcus aureus G7a [34] and Pichia guilliermondii [58].

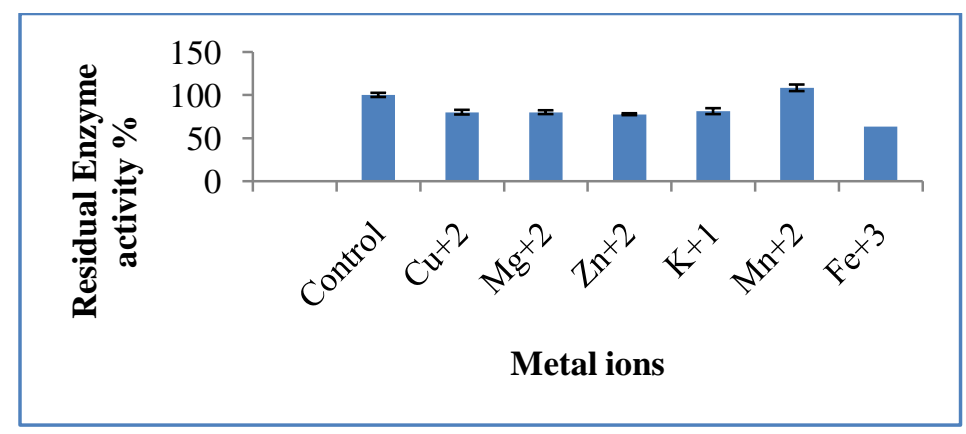

Figure18. Effect of Metal Ions on Activity of Inulinase from S. Maltophila D457

The effect of various thermal stabilizers on inulinase activity from S. maltophila D457 was analyzed. Glycerol exhibited a significant stabilizing effect on the enzyme activity (Figure 19). Glycerol having the best stabilizing effect could be as a result of preferential exclusion of the polyols with proteins, which increases with an increasing polyol size, resulting in an indirect interaction that prevent the protein from thermal unfolding [59]. Inulinase activity from the thermophilic bacterium Thermotoga maritime was also found to be enhanced in the presence of glycerol [60].

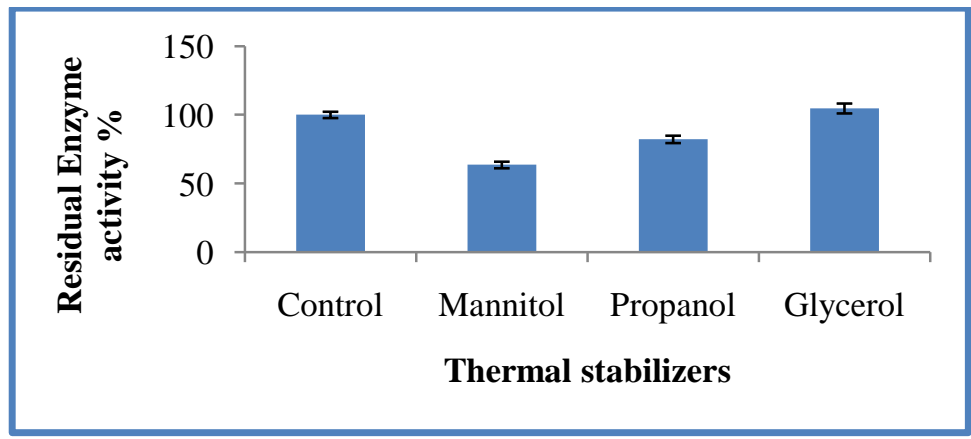

Figure19. Effect of Thermal Stabilizers on Activity of Inulinase from S. Maltophila D457 


\subsection{Analysis of Hydrolysis Products of Inulinase by TLC}

In order to confirm the exo- or endo- nature of the crude inulinase produced by S. maltophila D457, TLC analysis was carried out. The TLC analysis of the hydrolysis product of inulinase demonstrated that fructose was the major sugar produced during hydrolysis (Figure 20). This supports the view that inulinase is an end group cleaving enzyme [24]. It was concluded that the nature of inulinase produced by S. maltophila D457 is of exoinulinase type suggesting its potential application for the production of ultra-high fructose syrup. Similar results have been observed in case of Marinimicrobium sp. LS-A18 [20], Bacillus polymyxa [52] and Streptomyces sp. ALKC4 [23].

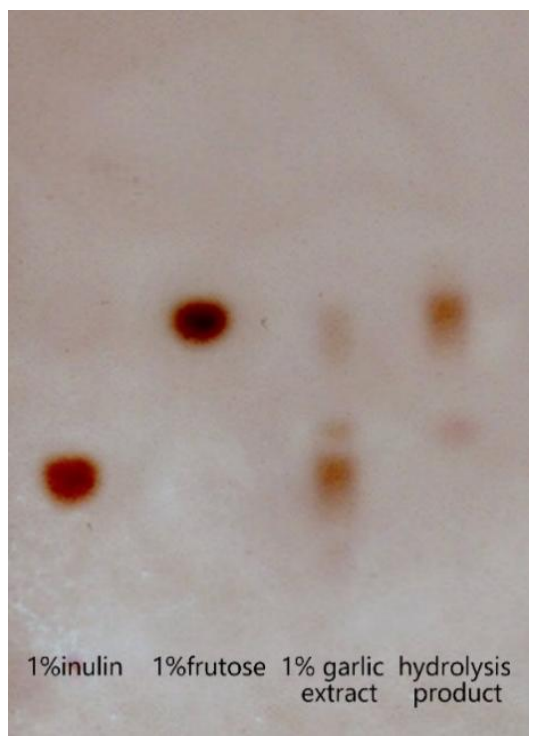

Figure20. TLC Analysis of Hydrolysate of Inulinase from S. Maltophila D457

\section{REFERENCES}

[1] Singh P. and Gill P. K., Production of Inulinases: Recent advantages, Food Technol. Biotechnol. 44(2), 151-162 (2006).

[2] Kalil S. J., Barboza M., Maugeri F. F. and Rodrigues M. I., Studies on the Adsorption of inulinase from Kluyveromyces marxianus ATCC 16045 onto an Ion Exchange Resin, Brazalian J Food Technol. 9(3), 223-228 (2006).

[3] Kaur N. and Gupta A. K., Applications of inulin and oligofructose in health and nutrition, J Biosc. 27(7), 703-714 (2002).

[4] Ricca E., Calabro V., Curcio S. and Iorio G., Fructose production by chicory inulin enzymatic hydrolysis: a kinetic study and reaction mechanism, Process Biochem. 44(4), 466-470 (2009).

[5] Rocha J. R., Catana R., Ferreira B. S., Cabral J. M. S. and Fernandes P., Design and characterization of an enzyme system for inulin hydrolysis, Food Chem. 95(1), 77-82 (2006).

[6] Tanaka K., Uchiyama, T. and Ito A., Formation of di-D-fructofuranose 1, 2': 2, 3'-dianhydride form by an extracellular inulase of Arthrobacter ureafaciens, Biochem. Biophys. Acta. 284(1), 248-256 (1972).

[7] Dilipkumar M., Rajasimmanand M. and Rajamohan N., Optimization of Inulinase production from garlic by Streptomyces sp. in solid state fermentation using statistical designs, Biotechnol. Res. Int. 1(1), 1-7 (2011).

[8] Chi Z. M., Zhang T., Cao T. S., Liu X. Y., Cui W. and Zhao C. H., Biotechnological potential of inulin for bioprocesses, Biores. Technol. 102(6), 4295-4303 (2011).

[9] Ertan F., Aktac T., Kaboglu C., Ekinci F. and Bakar E., Determination of optimum cultivation conditions on the production of inulinase from Rhizoctonia solani, Pak. J. Biol. Sc. 6(16), 13861388 (2003).

[10] Sharma A. D., Kainth S. and Gill P. K., Inulinase production using garlic (Allium sativum) powder as a potential substrate in Streptomyces sp., J. Food Eng. 77(3), 486-491 (2005).

[11] Mahmoud D., Mahdy E., Shousha W. G., Refaat H. W. and Ahmed F., Raw Garlic as a New Substrate for Inulinase Production in Comparison to Dry Garlic, Aus. J. Basic Appl. Sc. 5(10), 453-462 (2011). 
[12] Pandey A., Soccol C. R., Selvakumar P., Soccol V. T., Krieger N. and Fontana J. D., Recent developments in microbial inulinases, Appl. J. Biochem. Biotechnol. 81(1), 35-52 (1999).

[13] Kim Y. H., Nam S. W. and Chung B. H., Simultaneous saccharification of inulin and ethanol fermentation by recombinant Saccharomyces cerevisiae secreting inulinase, Biotechnol. Bioprocess. 3(2), 55-60 (1998).

[14] Gao L., Chi Z., Sheng J., Wang L., Li J. and Gong F., Inulinase-producing marine yeasts: evaluation of their diversity and inulin hydrolysis by their crude enzymes, Microbial Ecology. 54(4), 722-729 (2007).

[15] Pandey A, Soccol C. R., Selvakumar P., Soccol V. T., Krieger N. and Fontana J. D., Recent developments in microbial inulinases, Appl. Biochem. Biotechnol. 81(1), 35-52 (1999).

[16] Liu X. Y., Chi Z., Liu G. L., Wang F., Madzak C. and Chi Z. M., Inulin hydrolysis and citric acid production from inulin using the surface engineered Yarrowia lipolytica displaying Inulinase, Metabolic Engineering. 12(5), 469-476 (2010).

[17] Rowland I. R., Rumney C. J., Coutts J. T. and Lievense L. C., Effect of Bifidobacterium longum and inulin on gut bacterial metabolism and carcinogen-induced aberrant crypt foci in rats, Carcinogensis. 19(2), 281-285 (1998).

[18] Kango N., Production of inulinase using tap roots of dandelion (Taraxacum officinale) by Aspergillus niger, J. Food Engineering. 85(3), 473-478 (2008).

[19] Castro G. R., Baigori M. D. and Sineriz F., A plate technique for screening of inulin degrading microorganisms, J. Microbiol. Methods. 22(1), 51-56 (1995).

[20] Li A. X., Guo L. Z., Fu Q. and Lu W. D., A simple and rapid plate assay for screening of inulin degrading microorganisms using Lugol's iodine solution, Afr. J. Biotechnol. 10(46), 9518-952 (2011).

[21] Miller G. L., Use of dinitrosalicylic acid for determination of reducing sugar, Anal. Chem. 31(3), 426-428 (1959).

[22] Kang S. I., Chang Y. J., Oh S. J. and Kim S. I., Purification and properties of an endo-inulinase from an Arthrobacter sp., Biotechnol. Letters. 20(10): 983-986 (1998).

[23] Sharma A. D. and Gill P. K., Purification and characterization of heat-stable exo-inulinase from Streptomyces sp., J. Food Eng. 79(4), 1172-1178 (2007).

[24] Camelia N. and Gabriela B., Inulinases- a versatile tool for biotechnology, Inno. Romanian Food Biotechnol. 9(1), 1-11 (2011).

[25] Guimaraes L. H., Terenzi H. F., Polizeli M. L. and Jorge J. A., Production and characterization of a thermostable extracellular $\beta$-D-fructo-furanosidase produced by Aspergillus ochraceus with agro-industrial residues as carbon sources, Enz. Microb. Technol. 42(1), $52-57$ (2007).

[26] Muslim S. N., Ali A. M., Salman I. M., Israa M. S., Kadmy A. L., Muslim S. N., Detection of the optimal conditions for inulinase productivity and activity by Acinetobacter baumannii isolated from agricultural rhizosphere soil. Int. J. Advance. Chem. Engg. Biolog. Sc.2(1), 1-7 (2015).

[27] Zherebtsov N., Shelamova S. A. and Abramova I. N., Biosynthesis of inulinases by Bacillus bacteria, Appl. Biochem. Microbiol. 38(6), 634 -638 (2002).

[28] Aruna K., Amita Hati., Optimization of inulinase production by Bacillus sp. B51f isolated from rhizosphere soil of Agave sisalana. Int. J. Pure Appl. Biosc. 2(3): 161-176 (2014).

[29] Meenakshi S. S., Umayaparvathi, P., Manivasagan M., Arumugam and Balasubramanian T., Purification and characterization of Inulinase from marine bacterium, Bacillus cereus MU-31, Indian J. Geo-Marine Sc. 42(4), 510-515 (2013).

[30] Allais J. J., Lopez G. and Baratti J. C., Characterization and properties of an inulinase from a thermophilic bacteria, Carbohydr. Polym. 7(4), 277-290 (1987).

[31] Drent W. J. and Gottschal J. C., Fermentation of inulin by a new strain of Clostridium thermoautotrophicum isolated from Dahlia tubers, FEMS Microbiol. Lett. 78(2-3), 285-292 (1991).

[32] Gill P. K., Sharma A. D., Harchand R. K. and Singh P., Effect of media supplements and culture conditions on inulinase production by an actinomycete strain, Bioresource Technol. 87(3), 359362 (2003). 
[33] Souza-Motta C. M., Cavalcanti M. A., Lúcia A., Porto F., Moreira K. and Filho J. L., Aspergillus niveus Blochwitz 4128URM: New Source for Inulinase Production, Braz. Arch. Biol. Technol. 48(3), 343-350 (2005).

[34] Sheng J., Chi Z., Li J., Gao L. and Gong F., Inulinase production by the marine yeast Crytococcus aureus G7 and inulin hydrolysis by crude inulinases, Process Biochem. 42(5), 805811 (2007).

[35] Bharathi S., Saravanan D., Radhakrishnan M. and Balagurunathan R., Bioprospecting of marine yeast with special reference to Inulinase production, Int. J. Chem. Tech. Res. 3(3), 1514-1519 (2011).

[36] Pessoni R. A. B., Fgueiredo R. and Braga M. R., Extracellular inulinases from Penicillium janczewskii, J. Appl. Microbiol. 87(1), 141-147 (1999).

[37] Regina M. M., Gern S. A., Furlan J. L. and Ninow R. J., Screening for microorganisms that produce only endoinulinase, Appl. Microbiol. Biotechnol. 55(5), 632-635 (2001).

[38] Singh R. S., Dhaliwal R. and Puri M., Production of inulinase from Kluyveromyces marxianus YS-1 using root extract of Asparagus racemosus, Process Biochem. 41(7), 1703-1707 (2006).

[39] Selvakumar P. and Pandey A., Solis state fermentation for the synthesis of Inulinase from Staphylococcus sp. and Kluyveromyces marxianus, Process Biochem. 34(8), 851-855 (1999).

[40] Park J. P., Bae J. T., You D. J., Kim B. W. and Yun J. W., Production of inulooligosaccharides from inulin by a novel endoinulinase from Xanthomonas sp., Biotechnol. Letter. 21(12), 10431046 (1999).

[41] Park J. P. and Yun J. W., Utilization of chicory roots for microbial endoinulinase production. Lett. Applied Microbiol, 33(3), 183-187 (2001).

[42] Vullo D. L., Coto C. and Sineriz F., Characteristics of an Inulinase Produced by Bacillus subtilis 430A, a Strain Isolated from the Rhizosphere of Vernonia herbacea (Vell Rusby), Appl. Environ. Microbiol. 57(8), 2392-2394 (1991).

[43] Yokota A., Yamauchi O. and Tomita F., Production of inuliotriose from inulin by inulin degrading enzyme from Streptomyces rochei, Lett. Appl. Microbiol. 21, 330-333 (1995).

[44] Masomian M., Abd Rahman N. Z., Abu Bakar S. and Mahiran B., A unique thermostable and organic solvent tolerant lipase from newly isolated Aneurinibacillus thermoaerophilus strain HZ: physical factor studies, World J. Microbiol. Biotechnol. 26(9), 1693-1701 (2010).

[45] Ayyachamy M., Khelawan K., Pillay D., Permaul K. and Singh S., Production of inulinase by Xanthomonas campestris pv phaseoli using onion (Allium cepa) and garlic (Allium sativum) peels in solid state cultivation, Lett. Appl. Microbiol., 45(4), 439-444 (2007).

[46] Amith A. and Jayachandran K., Fermentative Production of the Extracellular Exo-acting Inulinase from a Novel Strain of Erwinia sp., Res. J. Biotechnol. 2(2), 45-49 (2007).

[47] Gupta A. K., Rathore P., Kaur N. and Singh R., Production thermal stability and immobilisation of inulinase from Fusarium oxysporum., J. Chem. Technol. Biotechnol. 47(3), 245-257 (1990).

[48] Mukherjee K. and Sengupta S., Purification and properties of a non-specific betafructofuranosidase (inulinase) from the mushroom Panaeolus papillonaceus, Canadian J. Microbiol. 33(6), 520-524 (1987).

[49] Cho Y. J., Shinha J., Park J. P., Yu J. W., Production of innulooligosaccharides from chicory extract by endoinulinase from Xanthomonas oryzae No. 5. Enzyme Microb Technol, 28, 439-45 (2001).

[50] Looten P., Blanchet P. D. and Vandecasteele J. P., The $\beta$-fructofuranosidase activities of a strain of Clostridium acetobutylicum grown on inulin, Appl. Microbiol. Biotechnol. 25(5), 419425 (1987).

[51] Tambara Y., Hormaza J. V., Perez, C., Leon A., Arrieta J. and Hernandez L., Structural analysis and optimized production of fructo-olgiosaccharides by levansucrase from Acetobacter diazotrophicus SRT4, Biotechnol. Lett. 21(2), 117-121 (1999).

[52] Kato K., Araki T., Kitamura T., Morita N., Moori., M. and Suzuki Y., Purification and properties of a thermostable inulinase ( $\beta$-D-fructan fructohydrolase) from Bacillus stearothermophilus KP1289, Starch. 51(7), 253-258 (1999). 
[53] Kwon H. J., Jeon S. J., You D. J., Kim K. H., Jeong Y. K., Kim Y. H., Kim Y. M. and Kim B. W., Cloning and characterization of an exoinulinase from Bacillus polymyxa, Biotechnol. Lett. 25(2), 155-159 (2003).

[54] Tohamy E. Y., Purification and Characterization of Exoinulinase Enzyme from Streptomyces grisenus, Pak. J. Biol. Sci. 9(5), 911-916 (2006).

[55] Kwon Y. M., Kim H. Y. and Choi Y. J., Cloning and characterization of Pseudomonas mucidolens exoinulinase, J. Microbiol. Biotechnol. 10(2), 238-243 (2000).

[56] Laowklom N., Chantanaphan R. and Pinphanichakarn P., Production, Purification and Characterization of Inulinase from a Newly Isolated Streptomyces sp. CP01, Natural Res. 3(3), 137-144 (2012).

[57] Dinarvand M., Ariff A. B., Moeini H., Masomian M., Mousavi S. S., Nahavandi R. and Mustafa S., Effect of extrinsic and intrinsic parameters on inulinase production by Aspergillus niger ATCC 20611, Electronic J. Biotechnol. 15(4), 9pages (2012).

[58] Gong F., Zhang T., Chi Z., Sheng J., Li J. and Wang X., Purification and characterization of extracellular inulinase from a marine yeast Pichia guilliermondii and inulin hydrolysis by the purified inulinase, Biotechnol. Bioprocess Engineer. 13(5), 533-539 (2008).

[59] Taravati A., Shokrzadeh M., Ebadi A. G., Valipour P., Hassan A. T. and Farrakhi F., Various effects of sugar and polyols on the protein structure and function: role as osmolyte on protein stability, W. Appl. Sci. J. 2(4), 353-362 (2007).

[60] Taylor L. S., York P. and Williams A. C., Protein denaturation by a chaotropic agent, Biochimica et Biophysica Acta 1. 253(1), 39-46 (1995). 